\title{
A population survey of the estuarine crocodile in the Ayeyarwady Delta, Myanmar
}

\author{
John Thorbjarnarson, Steven G. Platt and U. Saw Tun Khaing
}

\begin{abstract}
The estuarine crocodile Crocodylus porosus was formerly abundant in coastal regions of Myanmar, but is now known principally from the lower Ayeyarwady Delta. We conducted a survey during January 1999 to assess quantitatively the status of crocodile populations in protected areas of the lower delta. Spotlight counts were conducted along $275.4 \mathrm{~km}$ of waterways. Sixty-one crocodiles (50 juveniles, 4 subadults, 2 adults and 5 eyeshines) were observed in the Meinmahla Kyun Wildlife Sanctuary (MKWS), and the total population was estimated to be less than 100 . The Kadônkani and Pyindaye Reserved Forests (RF) apparently no longer support viable populations. Al-
\end{abstract}

\section{Introduction}

The estuarine crocodile Crocodylus porosus is the only species of crocodilian presently known to occur in Myanmar (Ross, 1998). Historically, the estuarine crocodile was widely distributed and abundant in coastal regions and major rivers (Mason, 1860; Theobald, 1868; Furnival, 1914; Smart, 1917; Symns, 1942), but populations are now believed to be greatly depleted (Caughley, 1980; Salter, 1983; Aung Moe, 1993, 1994). The southern delta of the Ayeyarwady (formerly spelled Irrawaddy) River probably harbours the only significant estuarine crocodile population remaining in the country (Aung Moe, 1993, 1994). However, a survey conducted in 1980 found few crocodiles (Caughley, 1980 ), and the current status of this population remains unknown (Aung Moe, 1994). Estuarine crocodile populations in Myanmar are currently listed on Appendix I of CITES and surveys have been accorded high priority by the IUCN Crocodile Specialist Group (Ross, 1998). We here report the results of an estuarine crocodile

John Thorbjarnarson (corresponding author; email: Jthorbjarnarson@wcs.org) and Steven G. Platt Wildlife Conservation Society, 185th St. and Southern Blvd., Bronx, New York, 10460-1099, USA.

U. Saw Tun Khaing Wildlife Conservation Society, Bldg. C-3, Aye Yeik Mon 1st St., Yadanamon Housing Ave., Hilling Township, Yangon, Myanmar.

Revised manuscript accepted for publication 20 May 2000 though crocodiles remain critically endangered in the region, a comparison with survey data from 1980 suggests localized recovery is occurring in MKWS. Population declines are attributed to a combination of commercial skin hunting, habitat loss, drowning in fishing nets and over-collection of living animals to supply crocodile farms. A programme of law enforcement, habitat protection and head-starting juveniles is necessary to ensure the continued survival of estuarine crocodiles in the Ayeyarwady Delta.

Keywords Ayeyarwady River, Crocodylus porosus, estuarine crocodile, Myanmar, population survey. survey conducted during January 1999 in the southern Ayeyarwady Delta. Our objectives were to assess quantitatively population status, make comparisons with earlier survey data and provide conservation recommendations based on these findings.

\section{Study area and methods}

The Ayeyarwady River is among the largest in Asia and drains much of northern and central Myanmar. The delta region begins about $90 \mathrm{~km}$ from the ocean, where the main river diverges into numerous channels flowing into the Bay of Bengal and Andaman Sea. The regional climate is tropical monsoonal, with a pronounced wet season from June to August. The delta is the most heavily populated region of the country (mean population density of $170 / \mathrm{sq} \mathrm{km}$ in 1983), and the regional economy is based on rice farming, fishing and the cultivation of nippa palm, betel nut and coconut. Mangroves are the predominant vegetation, but forests have been significantly degraded due to cutting for fuelwood and conversion to rice fields (Tin Maung Kyi, 1992).

Our survey efforts were concentrated on Meinmahla Kyun, a 136-sq-km island in the lower delta, designated as a wildlife sanctuary in 1994. Additionally, we surveyed rivers in the 48,514-ha Pyindaye Reserved Forest (RF) and 60,507-ha Kadônkani RF, east and west, respectively, of Meinmahla Kyun (Fig. 1).

A combination of daylight surveys and nocturnal spotlight counts was used to census crocodiles. 
Spotlight counts are used in crocodile surveys worldwide involving many species (e.g., Messel et al., 1981; Magnusson, 1982; King et al., 1994; Stuebing et al., 1994), and other methods of population estimation, such as mark-recapture, have confirmed the validity of this technique, particularly in open water habitats (Bayliss et al., 1986; Hutton \& Woolhouse, 1989).

Surveys were conducted from 8-m wooden boats equipped with long-shaft diesel outboard motors. Survey routes were selected based on accessibility at low tide, and attempts were made to revisit areas previously surveyed by Caughley (1980). Due to the fact that crocodiles often move into flooded vegetation during high tide, making them less visible and thereby potentially biasing count data (Messel et al., 1981), we conducted spotlight counts beginning $c$. $2 \mathrm{~h}$ before low tide and continuing 1-2h thereafter. Potential routes were traversed during the day to assess navigability and to search for basking crocodiles, tracks and slides. The coordinates (latitude and longitude in degrees, minutes and seconds) were determined for the beginning and endpoint of each survey with a Garmin 40 Global Positioning System (GPS), allowing replication by future workers, which is essential for long-term population monitoring programmes (King et al., 1994). A detailed description and map of each survey route is provided in Thorbjarnarson et al. (1999), copies of which have been archived at the Department of Forestry (Yangon, Myanmar), Wildlife Conservation Society (New York), and the Campbell Museum, Clemson University (Clemson, South Carolina).

Waterways on Meinmahla Kyun were classified based on width as main river channels $(>1 \mathrm{~km})$, primary channels $(c .100 \mathrm{~m}-1 \mathrm{~km})$, secondary channels (c. 5$100 \mathrm{~m}$ ) and tertiary creeks $(<5 \mathrm{~m})$. We estimated the percentage of each habitat type surveyed from a $1: 66,000$ map. Crocodiles were located at night with a 400,000 candlepower spotlight or battery-powered headlight, approached as closely as possible, and classified based on estimated total length (TL) as juveniles $(T L<120 \mathrm{~cm})$, subadults $(T L=120-200 \mathrm{~cm})$ or adults (TL $>200 \mathrm{~cm}$ ). When crocodiles submerged before TL could be determined, they were classified as 'eyeshine only' (EO).

Distance travelled during each survey was determined using 1:63,000 topographical maps, or estimated based on average boat speed measured with the GPS. Encounter rates were calculated as the number of crocodiles observed per kilometre of survey route, allowing quantitative comparison with previous survey data and providing a means to assess future population trends (Bayliss, 1987).

Single spotlight counts were conducted along most routes. Single counts provide an index of relative

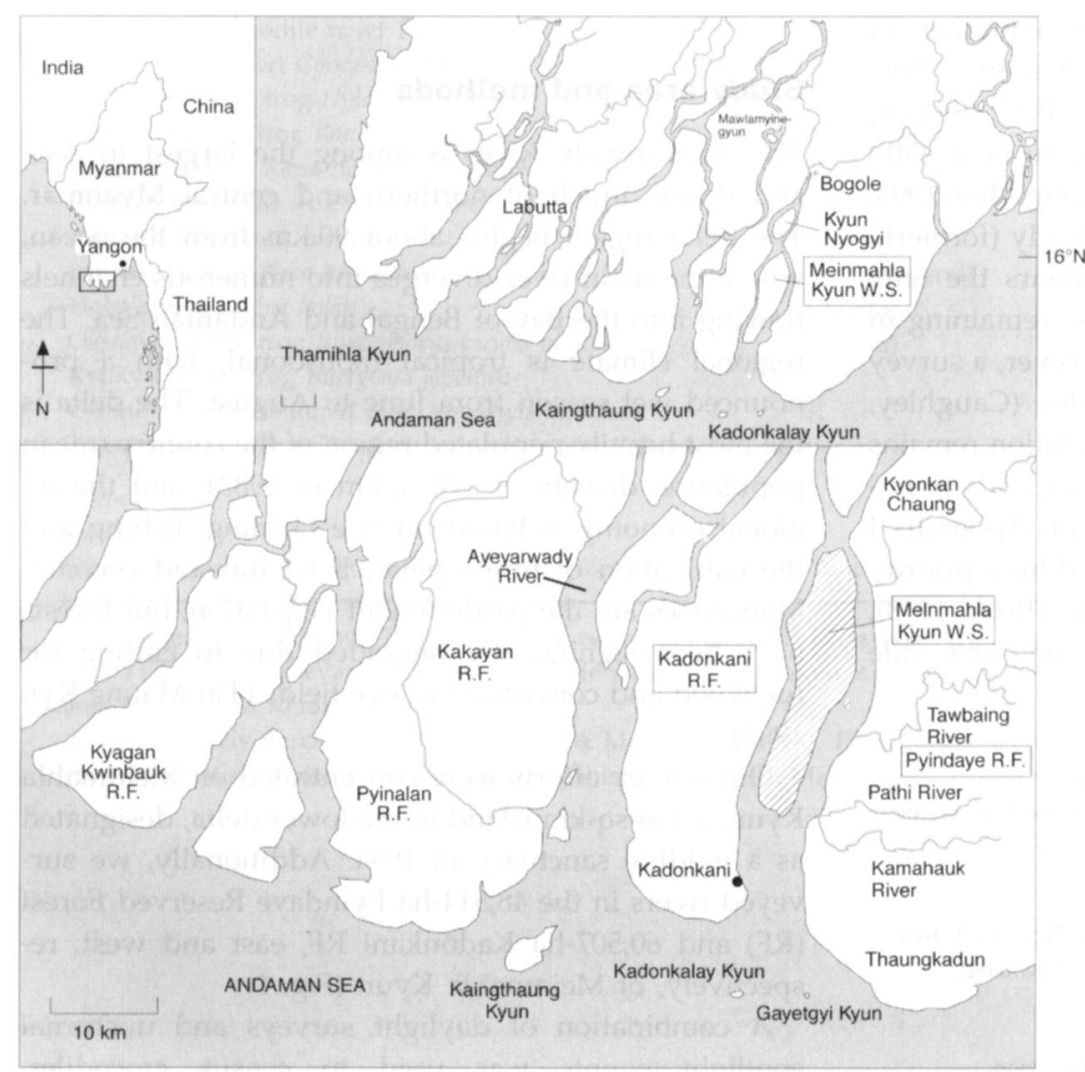

Fig. 1 Map of the lower Ayeyarwady Delta, Myanmar (modified from Van Dijk, 1993). 
density because not all crocodiles present are observed during a survey. However, the relationship between the count and actual population size is assumed to remain constant over time, and any change in counts should reflect a proportionate change in the total population (Bayliss, 1987). Relative indices are powerful when surrey techniques are standardized (Bayliss, 1987).

Replicated counts were conducted along Thabye Chaung Creek to estimate the 'sighting fraction' or the percentage of the population which is actually observed during a spotlight count. Messel et al. (1981) derived a method for estimating the sighting fraction of crocodiles in tidal waterways in Australia, and we believe it can be applied to the habitats we surveyed in Myanmar. The sighting fraction can be calculated from the formula (King et al., 1990)

$p=\frac{m}{(2 s+m) 1.05}$

where $p=$ percentage of population observed during an average survey, $m=$ mean survey value and $\mathrm{s}=$ standard deviation.

Total population size $(N)$ with 95 per cent confidence limits (Messel et al., 1981) can then be calculated as

$N=\frac{m}{p} \pm \frac{[1.96(s)]^{12}}{p}$.

Villagers and rural inhabitants were questioned throughout the project concerning attitudes towards crocodiles, past hunting and collecting practices, awareness of illegal hunting and general knowledge of crocodiles.

\section{Results}

We surveyed $456.9 \mathrm{~km}$ during the day and $275.4 \mathrm{~km}$ during spotlight counts in Meinmahla Kyun Wildlife Sanctuary (MKWS), and Pyindaye and Kadônkani RFs from 16 to 30 January 1999. Crocodile encounter rates are based entirely on the standardized nocturnal counts. Nevertheless, adult crocodiles were more likely to be seen during the day than at night; day surveys, therefore, were useful to understand the distribution of adults.

\section{Meinmahla Kyun Wildlife Sanctuary (MKWS)}

We conducted spotlight counts from 16 to 28 January, and observed 61 crocodiles along $169.7 \mathrm{~km}$ of survey route. These included 50 (81.9 per cent) juveniles, 4 (6.5 per cent) subadults, 2 (3.2 per cent) adults and 5 (8.1 per cent) eyeshines. Additionally, three adults were sighted during day surveys. The estimated TL of adults ranged from 3.0 to $4.5 \mathrm{~m}$. The mean encounter rate for all spotlight counts was $0.360 / \mathrm{km}$. However, this value is biased by repeated counts of the calibration survey, when five spotlight surveys were made in an area of relatively high crocodile density. Using only the first calibration survey, the overall crocodile encounter rate was $0.234 / \mathrm{km}$.

Fifty-eight (90.6 per cent) crocodiles were observed in primary channels, five (7.8 per cent) in secondary channels and one ( 1.5 per cent) in the main river. Crocodiles avoided main river channels and tertiary creeks. Main river channels were often several kilometres wide, subject to wind and wave action and heavily trafficked, while tertiary creeks held little water at low tide. Most juveniles and subadults were observed at the watermud-bank interface during spotlight counts. Due to differences in observability between juvenile and subadult crocodiles, and adult crocodiles we separated these two groups in our analysis of survey results.

\section{Population of juvenile and subadult crocodiles}

The mean encounter rate for juvenile and subadult crocodiles was $0.225 / \mathrm{km}$. Juvenile encounter rates were highest in primary and secondary channels and none were seen in the main river or in tertiary channels (Table 1). We found a mean of $7.6(\mathrm{SD}=0.55$; range $=$ 5-8) juvenile and subadult crocodiles during five calibration surveys in Thabye Chaung, and calculated a sighting fraction of 0.83 . From the estimated amount of habitat in each of the four habitat categories, the encounter rate of juvenile and subadult crocodiles, and the calculated sighting fraction, we estimate a total non-adult population of 44 crocodiles in MKWS (Table 1 ), with a 95 per cent confidence interval (CI) of $42.8-$ 45.7.

\section{Population of adult crocodiles}

Two adults were observed in primary channels during spotlight counts, for an encounter rate of $0.018 / \mathrm{km}$. Both of these animals were seen during calibration surveys and, calculating adult density using only the first calibration survey, the encounter rate was 0.009 / $\mathrm{km}$. This small sample precluded the calculation of a sighting fraction based on count variability. Instead, we estimated a sighting fraction based on the number of times adult crocodiles were observed during spotlight counts when we knew from day surveys that they were present. Because adults were encountered during only one of seven opportunities, we calculated a sighting fraction of 0.14 and estimated that 10 adults are present in MKWS (no 95 per cent CI could be calculated) (Table 1). Given that we observed five adults, and that there are probably at least two to three nesting females on the island, this figure probably underestimates the actual number of adults. Nevertheless, the total 
Table 1 Estimated population of estuarine crocodile in different habitats of Meinmahla Kyun Wildlife Sanctuary (MKWS), based on spotlight counts and the first of five calibration surveys

\begin{tabular}{lccccc}
\hline & Main river & Primary channels & Secondary channels & Tertiary channels & Total \\
\hline Mean encounter rate (juveniles-subadults) & 0.00 & 0.339 & 0.095 & 0.00 & 0.225 \\
Mean encounter rate (adults) & 0.00 & 0.018 & 0.00 & 0.00 & 0.009 \\
Kilometres surveyed & 10.5 & 70.9 & 31.6 & 2.6 & 115.6 \\
Total kilometres of habitat & 61.8 & 78.8 & 105.3 & 260.0 & 505.9 \\
Percentage habitat sampled & 17.0 & 90.0 & 30.0 & 1.0 & 22.8 \\
Estimated juvenile-subadult population & 0 & 32.2 & 0 & 0 & $c .14$ \\
Estimated adult population & 0 & 9.9 & $c .12$ & 0 & $c .10$ \\
Total population & 0 & $c .42$ & 54 \\
\hline
\end{tabular}

A sighting fraction of 0.83 and 0.14 was used to estimate populations of juveniles-subadults and adults, respectively

population of crocodiles (juveniles, subadults and adults) in MKWS is almost certainly less than 100.

\section{Pyindaye Reserved Forest (RF)}

Spotlight counts of three rivers in Pyindaye RF were conducted on 29 and 30 January; $105.7 \mathrm{~km}$ were surveyed but no crocodiles were observed. However, according to fishermen, a small number of crocodiles persist in the Pathi and Tawbaing Rivers, and 17 hatchlings were collected in 1998 from a tributary of $\mathrm{Ky}$ onkan Chaung, just outside the boundaries of Pyindaye RF. Additionally, in 1998 a fisherman was arrested in the Kyonkan Chaung for having three juvenile crocodiles in his possession. These reports indicate that a remnant population still exists in the Pyindaye RF and adjacent areas. Much of the Pyindaye RF has been converted to rice fields and the use of monofilament fishing nets is widespread.

\section{Kadônkani Reserved Forest (RF)}

We did not conduct spotlight counts of Kadônkani RF because Forestry Department personnel believed that crocodiles had been exterminated from this area. However, we conducted a day survey of the Yegyawgyi River on 22 January, and found numerous settlements, extensive mangrove clearance for rice cultivation and widespread use of monofilament fishing nets. One adult female crocodile remains in the area and has nested for 3 years (1996-98) along a creek surrounded by rice paddies; we observed six hatchlings and an adult, presumably the female, adjacent to this site.

\section{Crocodile nesting}

Four estuarine crocodile nesting sites have been identified in the Ayeyarwady Delta. While females tend to nest at the same site each year, dense riparian vegetation makes finding nests difficult; moreover, in- formation is difficult to obtain from villagers, who collect and sell hatchlings and regard these locations as trade secrets. Only one nest site has been found on MKWS, but we observed groups of hatchlings at sereral widely scattered localities, suggesting that nesting is occurring elsewhere on the island. Another nest site is known in the Kandônkani RF, and a nest was found in Pyindaye RF in 1998. A fourth nesting site was found in 1998 on Kya Kyun, a small island in the Bogale River about $16 \mathrm{~km}$ upstream from MKWS. Based on the available information, it is likely that no more than 10 nesting females inhabit the lower Ayeyarwady Delta.

\section{Discussion}

Historic records suggest that crocodiles were at one time distributed widely along the Myanmar coast (Thorbjarnarson et al., 1999). Outside of the Ayeyarwady Delta, the estuarine crocodile is known only from a few scattered individuals in the mangrove regions of Rakhine state (Platt, 2000). Our results indicate that the estuarine crocodile remains critically endangered in the lower Ayeyarwady Delta. Encounter rates in the delta are among the lowest reported (Table 2), which is particularly alarming when considered in the context of a general, widespread, regional decline. Caughley (1980) found encounter rates (Table 3) lower than those reported for hunting-depleted populations in northern Australia (Messel et al., 1981). Nineteen years later, we found a similar overall encounter rate $(0.122 / \mathrm{km}$ vs. $0.132 / \mathrm{km})$. However, Caughley (1980) observed most crocodiles in the Pyindaye RF, an area where we found crocodiles had been largely extirpated. Conversely, an increase in the encounter rate between present $(0.122 / \mathrm{km})$ and previous $(0.036 / \mathrm{km})$ surveys of MKWS suggests localized population recovery is occurring and underscores the importance of this sanctuary to the continued regional survival of the estuarine crocodile. 
Table 2 A comparison of estuarine crocodile encounter rates (crocodiles $\mathrm{km}$ ) reported from spotlight surveys of various habitats

\begin{tabular}{llll}
\hline Location & Habitat & Encounter rate & Source \\
\hline Northern Australia & & & \\
Adelaide River & River & 2.60 & Webb et al., 1986 \\
East Alligator River & River & 3.10 & Webb et al., 1986 \\
McArthur River & River & 0.20 & Webb et al., 1986 \\
Wearyan-Foelsche & River & 0.14 & Webb et al., 1986 \\
Papua New Guinea & Rivers & 0.56 & Kula \& Solmu, 1996 \\
& Lagoons & 7.00 & Kula \& Solmu, 1996 \\
Solomon Islands & Rivers creeks & 0.16 & Messel \& King, 1990 \\
& Lagoons & 3.51 & Messel \& King, 1990 \\
Sabah, East Malaysia & Bays channels & 0.11 & Messel \& King, 1990 \\
India & River & 0.40 & Stuebing et al., 1994 \\
\hline
\end{tabular}

We attribute population declines and continued rarity of the estuarine crocodile in the Ayeyarwady Delta to a combination of commercial hunting for skins and meat, habitat loss, incidental drowning in fishing nets and over-collection of living animals to supply crocodile farms. The estuarine crocodile has the most commercially valuable skin of any crocodilian (Ross, 1998). Uncontrolled commercial hunting began during the early 1950s, and is believed to be largely responsible for declines of the crocodile throughout Myanmar (Caughley, 1980; Salter, 1983; Aung Moe, 1993, 1994). Skins were sent to Yangon and later exported to Thailand or Singapore, while meat was sold in local markets. Skins were still being exported in the late 1970s (Anonymous, 1977; Whitaker \& Daniel, 1978), and locals maintain hunting continued until 1994, when Meinmahla Kyun was declared a wildlife sanctuary (Thorbjarnarson et al., 1999). The estuarine crocodile is now afforded complete legal protection under the Protection of Wildlife and Protected Areas Law of 1994 (Thorbjarnarson et al., 1999).

Habitat loss is undoubtedly the greatest threat to the continued viability of estuarine crocodile populations in the Ayeyarwady Delta. A series of RFs established by the Colonial Administration during the late 19th and early 20th centuries protected extensive tracts of mangrove forest in the lower delta. However, forest cover has declined by 83 per cent since 1924 , and most of the remaining forest is highly de- graded (Tin Maung Kyi, 1992). Forest destruction has largely resulted from an expansion of rice cultivation, and government authorities have done little to discourage encroachment into protected areas. Indeed, clearance of Reserved Forests is often officially sanctioned as a means of boosting agricultural productivity and acquiring needed foreign exchange. Furthermore, in some instances, agricultural clearance has been sponsored by international donor agencies. Funds from the World Bank, for example, allowed the Myanmar Irrigation Department to convert 10,900 ha of mangrove forest in the Pyindaye RF into rice fields during the 1980s (Caughley, 1980).

Compounding the problem of habitat loss is the widespread use of monofilament fishing nets in the lower delta. We found fishing nets stretched across the Kamahauk and Pathi Rivers at 500-m intervals, and a large numbers of floating nets, guided by boats and moving with the tides, in the Bogale and Kadônkani Rivers. Additionally, fishermen frequently enter MKWS at night and illegally set large numbers of monofilament nets, often completely obstructing channels. Crocodiles are known to become entangled and drown in monofilament nets (Platt \& Thorbjarnarson, 1997); it is likely, therefore, that incidental drowning represents a significant source of mortality. Given the small crocodile population, the loss of even a few individuals, especially breeding females, can have a major negative impact.
Table 3 Results of spotlight counts conducted during 1980 in the lower Ayeyarwady Delta (Caughley, 1980)

\begin{tabular}{llll}
\hline Location/river system & Number of crocodiles & Distance $(\mathrm{km})$ & Encounter rate (crocodiles/km) \\
\hline $\begin{array}{l}\text { Pyindaye Reserved Forest } \\
\text { Tawbaing }\end{array}$ & 3 & & \\
Pathi & 4 & 12.9 & 0.232 \\
Kamahauk & 8 & 66.1 & 0.287 \\
Meinmahla Kyun & 1 & 27.5 & 0.121 \\
Total & 16 & 121.0 & 0.036 \\
\hline
\end{tabular}


The collection of living crocodiles to supply commercial farms likewise contributed to a significant reduction of estuarine crocodiles in the lower delta. A crocodile farm was established in 1978 at Thaketa on the outskirts of Yangon, for conservation, education and tourism and the sustainable production of skins (Aung Moe, 1994). Hatchlings, juveniles and adult crocodiles were purchased from collection centres to stock the farm and, although some were collected elsewhere in Myanmar, the majority originated in the lower delta (Anonymous, 1977). The harvest, which continued until 1995, was initially managed by the military, and later by the People's Pearl and Fishery Corporation and the Fisheries Department. Harvest quotas were never established, and hatchling collection was extremely efficient (Thorbjarnarson et al., 1999). At least 19 teams were catching crocodiles in the lower delta by 1977, and Caughley (1980) estimated that nearly 100 percent of the annual production from the Pyindaye RF was being taken to the farm. Undoubtedly, little population recruitment occurred during this period, and the near total absence of intermediate-sized crocodiles noted during our survey is likely to be due to the sustained over-harvesting of juveniles.

In addition to the legal collection of live crocodiles, a parallel, illegal export market emerged in the late 1980s, in response to the rapidly expanding crocodile farming industry in South-east Asia. Beginning in 1988-89, boats from Thailand entering the delta to purchase fish also began buying juvenile and adult crocodiles. According to area residents, Thai boats would pay considerably more for crocodiles than the Thaketa farm. Prices paid were very high, and juveniles were purchased for as much as 4000 Kyats (US\$650) (Aung Moe, 1992). Due to its clandestine nature, the extent of this illegal trade is impossible to quantify, but our interviews suggest it was widespread. The trade largely ended when a military post was established at the mouth of the Bogale River and entry of Thai boats into the delta was restricted.

\section{Conservation recommendations}

With adequate protection and the presence of sufficient habitat, estuarine crocodile populations can rapidly recover from past over-exploitation. Populations depleted by commercial hunting in Northern Australia (Messel et al., 1981) increased at a mean annual rate of 56 percent following legal protection, and encounter rates in some rivers are now over 20 individuals $/ \mathrm{km}$ (Webb et al., 1994).

Furthermore, head-starting, a management strategy in which wild-caught hatchlings are reared in captivity until attaining a body size less vulnerable to predation and then released, has successfully augmented recovery efforts elsewhere. In a situation similar to Myanmar, one of the last surviving estuarine crocodile populations in India is restricted to a small region (c. $176 \mathrm{sq} \mathrm{km}$ ) within the Bhitarkanika Wildlife Sanctuary, Orissa. Both areas share similar problems, including a high human population density (300 people $/ \mathrm{sq} \mathrm{km}$ around the Bhitarkanika Sanctuary), harvesting of wood and the leasing of streams for fishing (Kar \& Bustard, 1983). Since 1975, a total of 1657 head-started crocodiles have been released in the Bhitarkanika, and the population has increased from 100 to over 600 today (Kar, 1992, 1994, 1996).

A head-starting programme was initiated in MKWS during 1996, but poor husbandry practices and inadequate infrastructure resulted in high mortality and depressed growth rates among juvenile crocodiles (Thorbjarnarson et al., 1999). If these problems can be resolved, the continuance of the programme is warranted; however, nests in MKWS should be allowed to hatch naturally and juveniles left in situ. Hatchlings should instead be collected from surrounding areas (e.g., Kadônkani and Pyindaye RFs), where survival probabilities are low.

Rigorous enforcement of existing protective legislation is urgently required. While current legislation is adequate for the protection of estuarine crocodiles in Myanmar, enforcement is often lax, and an illegal trade in eggs and hatchlings apparently continues, albeit on a much reduced scale (Thorbjarnarson ot al., 1999). Fishing is illegal within the MKWS, and prohibitions against the use of fishing nets must be enforced strictly to prevent the accidental drowning of crocodiles. Further mangrove clearance must be halted in the RFs, and serious consideration given to re-establishing mangroves in degraded areas with a high potential for restoration, not only for crocodiles and other wildlife but to improve fisheries production for the local communities. Finally, the Myanmar Forestry Department should initiate a long-term population monitoring programme to detect future population trends and evaluate the success of conservation strategies. Unless appropriate conservation measures are soon implemented, the continued survival of estuarine crocodile populations in the Ayeyarwady Delta is questionable.

\section{Acknowledgements}

Fieldwork in Myanmar was supported by grants from the Walt Disney Company Foundation. U Shwe Kyaw, Deputy Director General of the Myanmar Forestry Department, is thanked for granting us permission to visit the delta. Field assistance was provided by U Soe Lwin 
and staff of Meinmahla Kyun Wildlife Sanctuary. Further assistance and information were provided by $U$ B. K. Aung Moe, U Uga, U Aun Than, Dr Win Maung and Stev'e Johnson. Comments by G. Webb were most appreciated.

\section{References}

Anonymous (1977) Burma report. Crocodile Specialist Group New sletter, 12, 7 .

Aung Moe, B.K. (1992) Crocodile farming in Myanmar Naingan. Crocotile Specinlist Group Newoletter, 11, 9.

Aung Moe, B.K. (1993) Conservation, management and farming of crocodiles in Union of Myanmar. In Crocodiles. Procedings of the 2nd Regional (Eastern Asia, Oceania, Australnsia) Meeting of the Crocodile Specialist Group, pp. 9-11. Darwin, Northern Territories, Australia. IUCN-The World Conservation Union, Gland, Switzerland

Aung Moe, B.K. (1994) The status of crocodiles in Myanmar. In Crocodiles. Proceedings of the 12th Working Mecting of the Crocodile Specialist Group, pp. 24-27. IUCN-The World Conservation Union, Gland, Switzerland.

Bayliss, P. (1987) Survey methods and monitoring within crocodile management programmes. In Wildlife Management: Crocodiles and Alligators (eds G.J.W. Webb, S.C. Manolis and P.J. Whitehead), pp. 157-175. Surrey Beatty and Sons Pty. Ltd., Sydney.

Bayliss, P., Webb, G.J.W., Whitehead, P.J., Dempsey, K. \& Smith, A. (1986) Estimating the abundance of saltwater crocodiles, Crocodylus porosus Schneider, in tidal wetlands of the Northern Territory: a mark-recapture experiment to correct spotlight counts to absolute numbers, and the calibration of helicopter and spotlight counts. Australian Wildlife Research, 13, 309-320.

Caughley, G. (1980) Crocodiles in Burma. Unpublished report, Food and Agriculture Organization of the United Nations, Rome, Italy.

Furnival, J.S. (1914) Syriam District. Burma Gazetteer. Government Printing Office, Rangoon.

Hutton, J.M. \& Woolhouse, M.E.J. (1989) Mark-recapture to assess factors affecting the proportion of a Nile crocodile population seen during spotlight counts of Ngezi, Zimbabwe, and the use of spotlight counts to monitor crocodile abundance. Journal of Applied Ecology, 26, 381-395.

Kar, S.K. (1992) Conservation, research, and management of estuarine crocodiles Crocodylus porosus Schneider in Bhitarkania Wildlife Sanctuary, Orissa: India during the last 17 years. In Crocodiles. Proceedings of the 11th Working Meeting of the Crocodile Specialist Group, pp. 222-242. IUCN-The World Conservation Union, Gland, Switzerland.

Kar, S. (1994) Crocodile census in Orissa. Crocodile Specialist Group Newsletter, 13, 10-11.

Kar, S.K. (1996) Crocodile program in Orissa. Crocodile Specialist Group Newsletter, 15, 7.

Kar, S.K. \& Bustard, H.R. (1983) Saltwater crocodile attacks on man. Biological Conservation, 25, 377-382.
King, F.W., Espinal, M. \& Cerrato, L.C.A. (1990) Distribution and status of the crocodilians of Honduras. In Crocodiles. Proceedings of the 10th Working Meeting of the Crocodile Specialist Group, pp. 313-354. IUCN-The World Conservation Union, Gland, Switzerland.

King, F.W., Ross, J.P. \& Gutierrez, L.D. (1994) Survey of the status of the crocodilians of Nicaragua. In Crocodiles. Proceedings of the 12th Working Meeting of the Crocodile Specialist Group, pp. 121-161. IUCN-The World Conservation Union, Gland, Switzerland.

Kula, V.V. \& Solmu, G.C. (1996) Summary report on the status of Crocodylus porosus and Crocodylus novaeguineae in Papua New Guinea. In Crocodiles. Proceedings of the 13th Working Meeting of the Crocodile Specialist Group, pp. 363-395. IUCN-The World Conservation Union, Gland, Switzerland.

Magnusson, W.E. (1982) Techniques of surveying for crocodiles. In Crocodiles. Proceedings of the 5th Working Meeting of the Crocodile Specialist Group, pp. 389-403. IUCN - The World Conservation Union, Morges, Switzerland.

Mason, F. (1860) Notes on the Nations, Fauna, Flora and Minerals of Tenasserim, Pegu and Burma. Thomas, Stowe \& Ranney, Rangoon.

Messel, H. \& King, F.W. (1990) The status of Crocodylus porosus in the Solomon Islands. In Crocodiles. Proceedings of the 10th Working Meeting of the Crocodile Specialist Group, pp. 39-69. IUCN-The World Conservation Union, Gland, Switzerland.

Messel, H., Vorlicek, G.C., Wells, A.G. \& Green, W.J. (1981) Surveys of Tidal River Systems in the Northern Territory of Australia and their Crocodile Populations. Monograph No. 1. Pergamon Press, Sydney.

Platt, S.G. (2000) An Expedition into Central Rakhine State, Myanmar. Unpublished report, Wildlife Conservation Society, Bronx, New York.

Platt, S.G. \& Thorbjarnarson, J.B. (1997) Status and Life History of the American Crocodile in Belize. Belize Coastal Zone Management Project BZE/92/G31. Unpublished report, United Nations Development Programme, Global Environmental Facility, Belize City and New York.

Ross, P. (1998) Crocodiles. Status Survey and Conservation Action Plan Crocodile Specialist Group, 2nd edn. IUCN - The World Conservation Union, Gland, Switzerland

Salter, R.E. (1983) Summary of Currently Available Information on Internationally Threatened Wildlife Species in Burma. Unpublished report, Nature Conservation and National Parks Project Burma. Food and Agriculture Organization of the United Nations, Rangoon.

Smart, R.B. (1917) Akyab District. Burma Gazeteer Government Printing Office, Rangoon.

Stuebing, R.B., Ismail, G. \& Ching, L.H. (1994) The distribution and abundance of the Indo-pacific crocodile Crocodylus porosus in the Klias River, Sabah, East Malaysia. Biological Conservation, 69, 1-7.

Symns, J.A.M. (1942) The crocodile in Burma. Journal of the Bombay Natural History Society, 43, 107.

Theobald, W. (1868) Catalogue of reptiles of British Burma, embracing the provinces of Pegu, Martaban, and Tenasserim; with descriptions of new or little-known species. Journal of the Linnaean Society of Zoology, 1868, $4-67$. 
Thorbjarnarson, J., Platt, S.G. \& Khaing, S.W. (1999) Ecological Reconnaissance of Meinnahla Kyun Wildlife Sanctuary and Vicinity, Southern Ayeyarwady Delta, Myanmar. Unpublished report, Wildlife Conservation Society, Bronx, New York.

Tin Maung Kyi (1992) Reforestation Techniques Applied to the Ayeyarwady Mangroves. Unpublished report, UNDP/FAO Workshop on Conservation and Rehabilitation of Mangrove Resources in Myanmar. Food and Agriculture Organization of the United Nations, Yangon.

Van Dijk, P.P. (1993) Myanmar Turtles: Report on a Prelininary Survey of the Testudines of the Ayeyarwady Basin. Unpublished report, Turtle Recovery Program, The World Conservation Union-IUCN SSC Tortoise \& Freshwater Turtle Specialist Group, New York.

Webb, G.J.W., Bayliss, P.G. \& Manolis, S.C. (1986)

Population research on crocodiles in the Northern Territory, 1985-1986. In Crocodiles. Proceedings of the 8th Working Meeting of the Crocodile Specialist Group, pp. 22-59. IUCN-The World Conservation Union, Gland, Switzerland.

Webb, G.J.W., Manolis, S.C. \& Ottley, B. (1994) Crocodile management and research in the Northern Territory: 1992-1994. In Crocodiles. Proceedings of the 12th Working Meeting of the Crocodile Specialist Group, pp. 167-180. IUCN-The World Conservation Union, Gland, Switzerland.

Whitaker, R. \& Daniel, R.C. (1978) The status of Asian crocodiles. Tigerpaper, 5, 12-17.

\section{Biographical sketches}

John Thorbjarnarson is a conservation zoologist with the Wildlife Conservation Society (WCS), based in New York, where he co-ordinates the reptile conservation efforts in the International Programs department. He received his $\mathrm{PhD}$ from the University of Florida in 1991. His main interests are the ecology and conservation of reptiles, particularly crocodilians and turtles. With the SSC Crocodile Specialist Group he compiled the first IUCN SSC Crocodile Action Plan in 1992, and is carrying out crocodile fieldwork in China, Brazil and Cuba.

Steven G. Platt is responsible for the WCS reptile conservation programmes in south-eastern Asia. He received his $\mathrm{PhD}$ from Clemson University in 1996 on the ecology of Morelet's crocodile in Belize, and subsequently carried out American crocodile surveys in Belize for the Wildlife Conservation Society. Since 1998, he has been focusing on field studies of threatened turtles and crocodilians in Myanmar, Indonesia, Vietnam and Cambodia.

U. Saw Tun Khaing is the Myanmar Program Country Coordinator for the Wildlife Conservation Society. He received a BSC in Forestry from Yangon University and an MSc from Aberdeen University, Scotland. Since 1995 he has been managing a variety of programmes for protected area management and wildlife conservation in Myanmar. 